\title{
Pengembangan Lembar Kerja Peserta Didik (LKPD) Berbasis Masalah pada Pemecahan Konsep Matematis Siswa
}

\author{
Ari Tri Wijayanti ${ }^{1}$, Caswita $^{2}$, Sugeng Sutiarso ${ }^{3}$ \\ ${ }^{1}$ Universitas Lampung, ${ }^{2}$ Universitas Lampung, ${ }^{3}$ Universitas Lampung \\ triwijayantiari@gmail.com, ${ }^{2}$ mcaswita@gmail.com, \\ ${ }^{3}$ sugengsutiarso@yahoo.com
}

\begin{tabular}{l}
\hline \hline Article Info \\
\hline Article history: \\
Received April $11^{\text {th }}, 2019$ \\
Revised April $30^{\text {th }}, 2019$ \\
Accepted May $1^{\text {st }}, 2019$ \\
\hline
\end{tabular}

Keywords:

Student Worksheet;

Problem Base;

Understanding of

Mathematical Concepts

This study is a research and development by following the path of Borg \& Gall which includes 7 steps, namely preliminary research, planning, developing initial types / products, initial testing, major product revisions, field trials and revising operational products. The purpose of this study was to develop problem-based Student Worksheets in understanding students' mathematical concepts. The research problem was how to develop problem-based Student Worksheets on understanding mathematical concepts of students. The study was conducted at Manba'ul Ulum Gayau Sakti Middle School with the research subject of grade VIII students in the academic year 2018/2019. The results showed that the researchers analyzed, designed a Student Worksheets with good and valid responses in accordance with the provisions of Badan Standar Nasional Pendidikan (BSNP) through the validation results from experts so that the Student Worksheets was feasible to be used in learning. In addition, the results of the study show that in terms of covers, contents, and results, it is effectively used. This can be seen from the study of the effect of Student Worksheets more effectively than not using problem-based Student Worksheets on understanding mathematical concepts of students.

Kata Kunci:

LKPD;

Berbasis Masalah;

Pemahaman

\section{Abstrak}

Penelitian ini adalah penelitian dan pengembangan dengan mengikuti alur Borg \& Gall yang mencakup 7 (tujuh) langkah yaitu penelitian pendahuluan, 
84 | Wijayanti, Caswita, Sutiarso: Pengembangan Lembar Kerja Peserta Didik (LKPD) ...

Matematis
dan melakukan revisi terhadap produk operasional.
Tujuan penelitian ini adalah untuk mengembangkan
Lembar Kerja Peserta Didik (LKPD) berbasis masalah
pada pemahaman konsep matematis peserta didik
Adapun masalah penelitiannya adalah bagaimana
mengembangkan LKPD berbasis masalah pada
pemahaman konsep matematis peserta didik. Penelitian
dilaksanakan di SMP Manbaul Ulum Gayau Sakti
dengan subjek penelitian siswa kelas VIII semester ganjil
tahun pelajaran 2018/2019. Hasil penelitian
menunjukkan bahwa peneliti menganalisis, mendesain
suatu LKPD dengan respon yang baik dan valid sesuai
ketentuan Badan Standar Nasional Pendidikan (BSNP)
melalui hasil validasi dari para ahli sehingga LKPD
layak digunakan dalam pembelajaran. Selain itu hasil
penelitian menunjukan bahwa dilihat dari segi sampul,
isi, maupun hasilnya efektif digunakan. Hal ini terlihat
dari penelitian pengaruh LKPD lebih efektif dari pada
tidak menggunakan LKPD berbasis masalah pada
pemahaman konsep matematis peserta didik.

\section{PENDAHULUAN}

Matematika merupakan salah satu ilmu pokok yang digunakan untuk membantu memahami bidang studi lain, seperti kimia, fisika, farmasi, arsitektur, ekonomi, geografi, dan lain sebagainya. Selain berfungsi sebagai landasan atau dasar dalam bidang studi lain, matematika juga berperan dalam memajukan daya pikir manusia agar dapat berpikir kritis, logis, dan praktis, serta berjiwa kreatif dan positif. Sehingga secara tidak langsung matematika dapat membantu perkembangan teknologi dan ilmu pengetahuan.

Melihat peran matematika tersebut, maka kemampuan matematika penting untuk dikembangkan. Sebelum dilakukan pengembangan, maka perlu diketahui kemampuan matematika itu sendiri. Kemampuan matematika terdiri dari pemahaman konsep, berpikir kritis dan kreatif. Kemampuan matematika salah satunya dapat di lihat dari hasil survey Trends in International Mathematics and Science Study (TIMSS) yang 
dilaksanakan setiap empat tahun sekali dari tahun 1999, 2003, 2007, dan 2011. Berdasarkan hasil survei tersebut, pada keikutsertaan pertama kali tahun 1999 ternyata Indonesia berada pada peringkat 34 dari 38 negara. Pada tahun 2003 Indonesia berada pada peringkat 34 dari 46 negara, dan peringkat Indonesia pada TIMSS tahun 2007 turun menjadi peringkat 36 dari 48 negara.

Skor standar internasional untuk penilaian tersebut dibagi menjadi tiga kategori yaitu mahir 625, tinggi 550, sedang 475 dan rendah 400 dan hasil yang dicapai siswa Indonesia termasuk pada kategori rendah, jauh dari kategori mahir (625) dimana pada kategori mahir ini peserta didik diharapkan dapat mengorganisasikan informasi, membuat perumusan, memecahkan masalah tidak rutin, mengambil dan mengajukan argumen pembenaran simpulan. Pada kategori mahir inilah yang sebenarnya ingin dicapai dalam kurikulum pendidikan matematika disekolah (Napitupulu, 2008).

Melihat dari hasil survei tersebut, kemampuan matematika yang dituntut adalah kemampuan berpikir kreatif. Untuk mencapai tahapan berpikir kreatif, maka peserta didik sudah harus melampaui tahapan pemahaman konsep, serta berpikir kritis. Berdasarkan hasil observasi di SMP Manba'ul Ulum, peserta didik memiliki kemampuan pemahaman konsep yang rendah. Jangankan untuk berpikir kritis ataupun kreatif, kemampuan pemahaman konsep saja masih jauh dari yang diharapkan. Hal ini dipengaruhi oleh beberapa faktor, diantaranya, yaitu sistem sekolah yang berbasis boarding school atau pondok pesantren, yang mewajibkan peserta didik belajar serta aktivitas keagamaan dalam kurun waktu kurang lebih 20 jam. Artinya, peserta didik hanya memiliki waktu untuk tidur kurang lebih 4 jam. Dalam rentang waktu istirahat yang cukup singkat tersebut peserta didik sering terlihat mengantuk di kelas, serta kurang semangat dalam belajar. Faktor lain yaitu input dari sekolah ini sendiri, 98\% peserta didik berasal dari keluarga yang kurang mampu, terpencil, serta motivasi mereka adalah ke pondok pesantrennya, hal ini juga menyebabkan semangat yang kurang untuk belajar di sekolah. Melihat hal tersebut, guru biasanya sering kasihan serta tidak memaksa 
86 | Wijayanti, Caswita, Sutiarso: Pengembangan Lembar Kerja Peserta Didik (LKPD) ...

peserta didik untuk belajar, tapi lebih mengarahkan ke arah belajar mandiri. Hanya saja keterbatasan sumber belajar menjadi faktor penghambat selanjutnya.

Berdasarkan hal tersebut, perlu dikembangkan sebuah kreasi bahan ajar yang menarik untuk mereka mau belajar. Bahan ajar bisa berupa berbasis komputer maupun cetak, Menurut Abi Fadila "Pada fungsi ini media berbasis komputer dan media cetak sama-sama dapat meningkatkan mutu hasil belajar matematika siswa. Hal ini terbukti dari hasil belajar matematika siswa yang memenuhi KKM (Kriteria Ketuntasan Minimum)". Bahan ajar ini lebih dikemas ke dalam aktivitas peserta didik, agar peserta didik tidak mengantuk, sehingga penulis berinisiatif mengembangkan sebuah Lembar Kerja Peserta Didik (LKPD). Menurut Kaymakci (2012), LKPD merupakan salah satu bahan ajar yang berperan penting dengan memberikan berbagai penugasan yang relevan dengan materi yang diajarkan, sehingga penggunaannya dapat membantu untuk mencapai tujuan pembelajaran. LKPD ini memodifikasi dari sebuah permainan sehingga peserta didik dapat belajar sambil bermain. LKPD ini diberikan setelah peserta didik menerima materi terlebih dahulu.

Berdasarkan latar belakang di atas, maka dilakukan penelitian untuk mengembangkan LKPD berbasis masalah pada pemahaman konsep matematis. Tujuan penelitian ini adalah mengetahui hasil pengembangan LKPD berbasis masalah pada pemahaman konsep matematis.

\section{METODE PENELITIAN}

Penelitian ini adalah penelitian Research and Development (R\&D) atau penelitian pengembangan. Penelitian ini mengikuti alur Borg \& Gall (2008) dengan langkah-langkah (1) melakukan penelitian pendahuluan (pra survei); (2) melakukan perencanaan; (3) mengembangkan jenis/bentuk produk awal; (4) melakukan uji coba tahap awal; (5) melakukan revisi terhadap produk utama; (6) melakukan uji coba lapangan; (7) melakukan revisi terhadap produk operasional; (8) melakukan uji lapangan operasional; (9) melakukan revisi terhadap produk akhir; (10) melakukan desiminasi dan implementasi produk. 
Pelaksanaan penelitian ini hanya sampai pada langkah ke tujuh yaitu melakukan revisi terhadap produk operasional. Produk yang dikembangkan oleh peneliti adalah LKPD matematika berbasis masalah untuk meningkatkan pemahaman konsep matematis.

Penelitian dilakukan di SMP Manba'ul Ulum Gayau Sakti. Subjek penelitian adalah siswa kelas VIII dengan jumlah siswa 24 orang, dilakukan pada semester ganjil tahun pelajaran 2018/2019. Teknik pengumpulan data pengembangan yang disusun dalam penelitian ini adalah (1) data validasi para ahli kemudian dianalisis secara deskriptif dengan menelaah hasil penilaian para ahli terhadap perangkat pembelajaran; (2) data basis masalah diperoleh dengan catatan lapangan, lembar observasi dan wawancara.

\section{HASIL PENELITIAN DAN PEMBAHASAN}

LKPD berabasis masalah yang dimaksud disini merupakan LKPD yang didasarkan pada masalah. LKPD diharapkan dapat membangun pengetahuan melalui masalah yang diberikan. Dari masalah yang disajikan, peserta didik diharapkan dapat memecahkan masalah tersebut berdasarkan pengetahuan yang telah ada, kemudian membentuk pengetahuan-pengetahuan baru hingga terbentuk suatu konsep lengkap matematika. Berikut bentuk LKPD yang penulis buat terlihat pada Gambar 1.

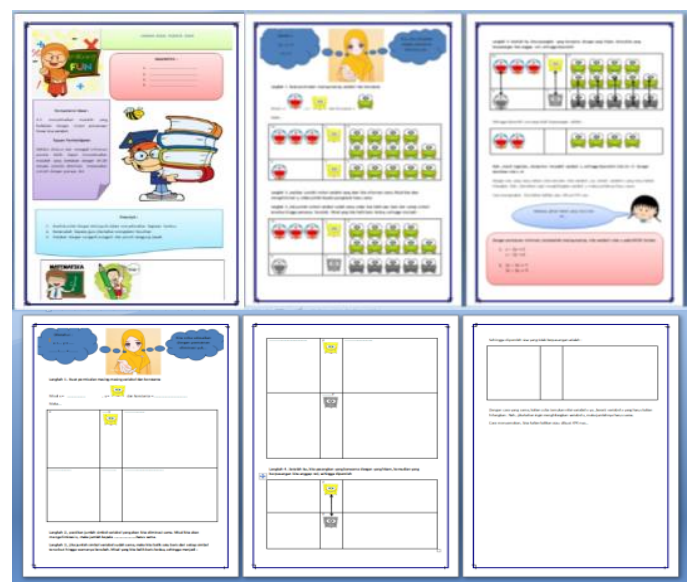

Gambar 1. Bentuk LKPD 
88 | Wijayanti, Caswita, Sutiarso: Pengembangan Lembar Kerja Peserta Didik (LKPD) ...

Penelitian ini mengikuti alur Borg \& Gall (2008), berdasarkan penelitian pengembangan LKPD yang telah dilakukan di SMP Manba'ul Ulum diperoleh hasil tahapan tersebut yaitu pada tahapan yang pertama peneliti melakukan observasi berupa analisis potensi dan masalah yang ada di SMP Manba'ul Ulum. Potensi dan masalah pada sekolah tersebut yaitu masih terbiasanya peserta didik dalam menggunakan bahan ajar cetak seperti buku, akan tetapi buku yang digunakan masih buku-buku lama dan masih ada guru yang belum memaksimalkan kemampuannya dalam pembuatan sebuah LKPD walaupun sudah sering mengikuti pelatihan. Selain itu, dengan adanya tuntutan pada kurikulum 2013 dimana siswa dituntut aktif dalam pembelajaran dengan melihat dan memanfaatkan lingkungan sekitar. Dalam hal keterbatasan bahan ajar yang digunakan guru dan peserta didik terbatas hanya mengandalkan satu buku yang berupa rangkuman materi serta soal latihan. Tidak ada penjabaran yang berarti pada buku yang digunakan. Selain itu, hanya ada satu buku paket bantuan dari pemerintah yang berbasis kurikulum 2013, hanya saja buku ini adalah buku edisi pertama belum direvisi serta guru dan peserta didik masih kesulitan untuk memahami materi khususnya pada materi persamaan linier dua variabel, yang mengakibatkan pemahaman konsep siswa menjadi rendah. Selain itu, belum ada LKPD pegangan peserta didik baik dari penerbit dan hasil karya guru.

Melihat dari masalah dan potensi yang ada, maka pada tahapan kedua yaitu peneliti mulai merencanakan pengembangan LKPD. LKPD yang dibuat yaitu LKPD berbasis masalah dengan memperhatikan pemahaman konsep peserta didik materi yang diambil adalah persamaan linier dua variabel. Dimana pemahaman konsep itu sendiri menurut Kesumawati "Pemahaman konsep merupakan salah satu kecakapan atau kemahiran matematika yang diharapkan dapat tercapai dalam belajar matematika yaitu dengan menunjukkan pemahaman konsep matematika yang dipelajarinya, menjelaskan keterkaitan antar konsep dan mengaplikasikan konsep atau algoritma secara luwes, akurat, efisien, dan tepat dalam pemecahan masalah". 
Tahap selanjutnya adalah tahap ketiga, dimana pada tahapan ini peneliti mulai mengembangkan jenis/produk awal. Produk awal LKPD dikembangkan dengan memperhatikan Standar Kompetensi dan Kompetensi inti yang ada, kemudian dan dengan beberapa bahan rujukan buku seperti buku Kurikulum 13 Matematika Kelas VIII dengan memperhatikan muatan materi dan diperoleh bahwa desain produk awal penelitian pengembangan LKPD adalah menentukan rancangan pengembangan LKPD, menentukan muatan LKPD dengan memilih materi persamaan linier dua variabel, dan penyusunan instrumen pembelajaran.

Pada tahapan yang keempat yaitu uji tahap awal, tahapan ini dilakukan guna mencari respon awal dari 7 siswa yang diberikan pembelajaran menggunakan LKPD yang dibuat. Dengan adanya respon akan memudahkan kita dalam mengevaluasi dan bahan perbaikan LKPD. Berdasarkan respon tersebut didapat rata-rata respon siswa sebesar 2.73 dengan hasil $68 \%$ responden yang artinya memberikan respon baik. Walaupun peserta didik memberikan respon yang baik, peneliti masih harus menyempurnakan LKPD tersebut, yaitu dengan melakukan revisi.

Pada tahapan selanjutnya yaitu tahapan kelima. Pada tahapan ini, peneliti melakukan revisi terhadap produk utama yang sudah melalui tahapan respon siswa dan guru. Setelah dilakukan revisi, peneliti melakukan uji ahli yaitu kepada tiga ahli materi dan tiga ahli media, dimana rata-rata hasil uji tersebut dapat dilihat pada grafik di bawah ini:

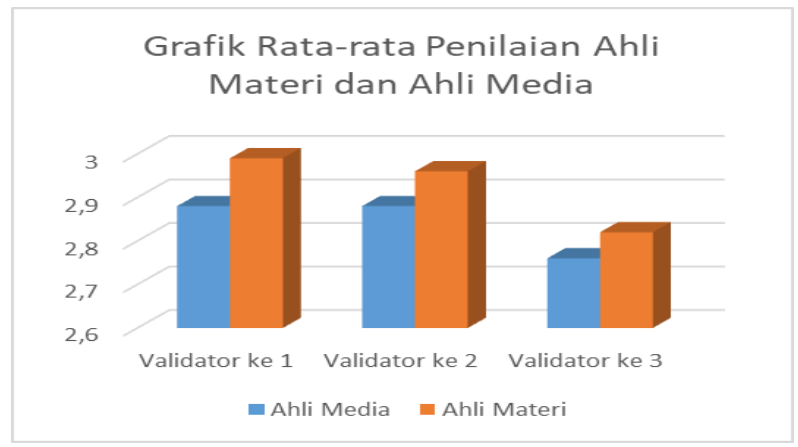

Grafik 1. Rata- rata Penilaian Ahli 
90 | Wijayanti, Caswita, Sutiarso: Pengembangan Lembar Kerja Peserta Didik (LKPD) ...

Hasil rata-rata uji ahli media masih menunjukkan nilai sebesar 2,84 yang berarti bahwa rata-rata penilaian ahli masih menunjukkan hasil yang cukup baik dan pada ahli materi juga demikian, dengan hasil 2,92 menunjukkan hasil cukup baik. Dengan demikian peneliti masih melanjutkan revisi dengan mengujicobakannya kembali.

Uji coba berikutnya merupakan tahapan ke enam, dimana peneliti melakukan uji lapangan dengan memberikan pembelajaran menggunakan LKPD. Sehingga peneliti melanjutkan pada uji kemenarikan terhadap 15 responden. Jumlah yang peneliti uji kemenarikan kepada 15 peserta didik. Penelitian dengan respon dari 15 responden hanya 1 yang memberikan respon cukup menarik dan 14 memberi respon sangat menarik.

Setelah melakukan uji kemenarikan peneliti melakukan revisi kembali. sebelum menggunakannya. Pada tahap ke tujuh ini, peneliti melakukan revisi terhadap produk operasional, peneliti mengujikan kepada ahli materi dan media dengan hasil dapat dilihat pada grafik sebagai berikut.

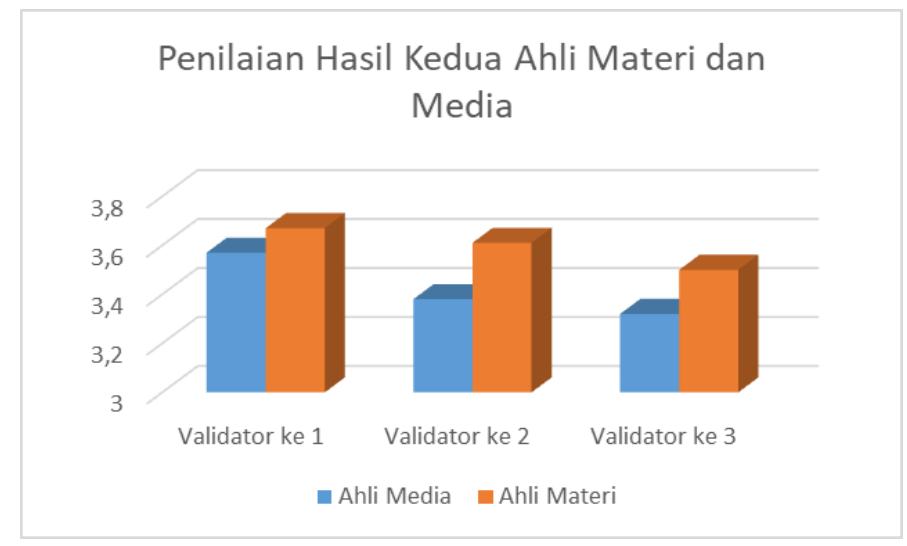

Grafik 2. Hasil Penilaian Ahli

Pada hasil tersebut terlihat bahwa ada peningkatan penilaian dari ahli materi dan media dari penilaian sebelumnya. Pada tahap ini, rata-rata respon penilaiannya adalah 3,50 dengan kategori sangat baik. 
Hasil tersebut membuat peneliti untuk melanjutkan tahap berikutnya yaitu menguji efektifitas dan perbandingan menggunakan uji t. Sebelum menguji dengan uji t, peneliti melakukan uji prasyarat yaitu sampel berdistribusi normal dan homogen. Setelah dilakukan pengujian, menghasilkan bahwa ada pengaruh penggunaan bahan ajar menggunakan LKPD daripada tidak menggunakan LKPD. Dengan hasil, pembelajaran menggunakan LKPD lebih baik daripada dengan yang tidak menggunakannya.

\section{SIMPULAN}

Berdasarkan hasil penelitian didapat bahwa pengembangan LKPD berbasis masalah pada pemahaman konsep matematis dapat meningkatkan pemahaman konsep peserta didik dengan baik dan menarik. Selanjutnya saran kepada peneliti selanjutnya yaitu terus mengembangkan LKPD pada materi yang lain, untuk memperkaya khasanah ilmu dan sumber bahan ajar.

\section{DAFTAR PUSTAKA}

Abi Fadila, (2016). Perbandingan Hasil Belajar Matematika Antara Penggunaan Media Berbasis Komputer dan Cetak. Jurnal EDuMath, 2(1), 59-65. Retrieved from http://ejournal.stkipmpringsewu-lpg.ac.id/index.php/edumath/ article/download/158/109

Afrilianto, M. (2012). Peningkatan Pemahaman Konsep dan Kompetensi Strategis Matematis Siswa SMP dengan Pendekatan Metaphorical Thinking. Jurnal Ilmiah Program Studi Matematika STKIP Siliwangi Bandung, 1(2), 192-202. Retrieved from doi:https://doi.org/10.22460/infinity.v1i2.p192-202

Borg \& Gall. (2003). Education Research. New York : Allyn and Bacon I M Dwi, H Arif, and K Sentot. (2013). Pengaruh Strategi Problem Based Learning Berbasis ICT Terhadap Pemahaman Konsep dan Kemampuan Pemecahan Masalah Fisika. Jurnal Pendidikan Fisika Indonesia, 9(5), 8-17. Retrieved from https://journal.unnes.ac.id/ nju/index.php/JPFI/article/view/2575/2628 
92 | Wijayanti, Caswita, Sutiarso: Pengembangan Lembar Kerja Peserta Didik (LKPD) ...

Kaymakci. (2012). A Review of Studies on Worksheets in Turkey. Retrieved from https://www.researchgate.net/publication/

303804536_A_Review_of_Studies_on_Worksheets_in_Turkey

Kesumawati, Nila. (2008). Semnas Matematika dan Pendidikan

Matematika, 229-35. Retrieved from

https://eprints.uny.ac.id/6928/1/P-18 Pendidikan (Nila K).pdf

Mahir, Nevin. (2009). Conceptual and Procedural Performance of

Undergraduate Student in Integration. International Journal of

Mathematical Education in Science and Technology, 40(2), 201-11.

Retrieved from https://www.tandfonline.com/doi/abs/10.1080/ 00207390802213591

Napitupulu dan E. Elvis. (2008). Peran Penalaran dalam Pemecahan Masalah Matematika. Prosiding Seminar Nasional Matematika dan Pendidikan Matematika. Retrieved from http://eprints.uny.ac.id/6923/1/P-14\%20Pendidikan\%28Elvis\%20 Napitupulu\%29.pdf 